\title{
The Relationship between Magnesium Level with Glucose Regulation and Amount of Proteinuria in Type 2 Diabetes
}

\author{
Ali Kirik (Corresponding author) \\ Department of Medicine, Division of Internal Medicine, \\ Balikesir University School of Medicine, Balikesir, Turkey \\ E-mail: alikirik87@hotmail.com \\ Zeynep Ata \\ Department of Medicine, Division of Internal Medicine, \\ Balikesir University School of Medicine, Balikesir, Turkey \\ E-mail: medicus86@hotmail.com \\ Emel Aslan Bozyel \\ Department of Medicine, Division of Internal Medicine, \\ Balikesir University School of Medicine, Balikesir, Turkey \\ E-mail: emelaslan006@hotmail.com
}

\begin{abstract}
Diabetes Mellitus is a globally common, chronic metabolic disease. In progression of disease itself, peripheral insülin resistance and insülin secretion disorders can be observed. In addition there can be electrolyte disorders such as magnesium, calcium and iron deficiency. Magnesium levels may have significant role in the clinical course of the disease. In this study, it is aimed to observe relationship among magnesium levels glucose regulation and proteinuria.

In this cross sectional study, 200 diabetic patients were examined for magnesium levels. Blood parameters and proteinuria levels were determined and the patients were divided into two groups as hypomagnesemic and normomagnesemic. Glucose levels, HbA1c and proteinuria levels were compared between groups.

Of the cases $(n=200), 59(29.5 \%)$ were male and $141(70.5 \%)$ were female. The frequency of hypomagnesemia was $38.5 \%$. The incidence of hypomagnesemia in women $(46.1 \%)$ was significantly higher than in men $(20.3 \%)$ ( $p=0.001)$. In hypomagnesemia group, glucose level $(179.7 \pm 60.2 \mathrm{mg} / \mathrm{dL})$ was higher than normomagnesemia group $(160.7 \pm 52 \mathrm{mg} / \mathrm{dL})(p=0.013)$. However, no statistically significant difference was observed between the groups in terms of HbA1c level. Proteinuria levels were higher in hypomagnesemia group $(0.18 \pm 0.12 \mathrm{mg} / \mathrm{mg})$ than normomagnesemia group $(0.14 \pm 0.05 \mathrm{mg} / \mathrm{mg})$ $(p=0.013)$.

Magnesium deficiency is a common condition in diabetic patiens and may have negative effects on glucose regulation and proteinuria. Randomized controlled trials are needed to clarify the role of magnesium in diabetic complications.
\end{abstract}

Keywords: Diabetes Mellitus, magnesium, proteinuria

DOI: $10.7176 / \mathrm{JSTR} / 5-10-02$

\section{Tip 2 Diyabette Magnezyum Düzeyi ile Glukoz Regülasyonu ve Proteinüri Miktarı Arasındaki İlișki}

Özet

Diyabetes Mellitus küresel ölçekte yaygın görülen kronik metabolik hastalıktır. Hastalık patogenezinde insülin sekresyon bozukluğu ve periferik insülin direnci gelişimi var olmakla beraber hastalığın seyrinde demir, magnezyum, kalsiyum gibi element düzeylerinde değişiklik izlenebilir. Magnezyum düzeyindeki 
azalma diyabetin klinik seyri için önemli olabilir. Bu çalışmada tip 2 diyabetik hastalarda magnezyum düzeyi ile glukoz regülasyonu ve proteinüri arasındaki ilişkinin incelenmesi amaçlandı.

Kesitsel yapılan bu çalışmada 200 diyabetik hasta magnezyum seviyeleri açısından incelendi. Hastalara ait kan parametreleri ve proteinüri düzeyi belirlenip hastalar hipomagnezemik ve normomagnezemik olmak üzere iki gruba ayrıldı. Gruplar arasındaki glukoz düzeyi, HbA1c ve proteinüri miktarı kıyaslandı. Olguların (n= 200) 59'u (\%29,5) erkek ve 141'i (\%70,5) kadın olup, hipomagnezemi sılı̆̆ı̆ın \%38,5 olduğu saptandı. Kadınlarda hipomagnezemi görülme oranı $(\% 46,1)$ erkeklere $(\% 20,3)$ göre anlamlı olarak yüksek bulundu ( $p=0,001)$. Hipomagnezemi grubunda glukoz düzeyinin $(179,7 \pm 60,2 \mathrm{mg} / \mathrm{dl})$, normomagnezemi grubuna göre $(160,7 \pm 52,3 \mathrm{mg} / \mathrm{dl})$ daha yüksek olduğu saptandı $(p=0,013)$. Bununla birlikte gruplar arasında HbA1c düzeyi yönünden istatistiksel anlamda bir farklılık gözlenmedi. Proteinüri düzeyi hipomagnezemi grubunda $(0,18 \pm 0,12 \mathrm{mg} / \mathrm{mg})$, normomagnezemi grubuna göre $(0,14$ $\pm 0,09 \mathrm{mg} / \mathrm{mg})$ daha yüksek saptand1 $(p=0,013)$.

Magnezyum eksikliği diyabetik hastalarda sık izlenen bir durum olup glukoz regülasyonu ve proteinüri oluşumu üzerine olumsuz etki yapabilir. Diyabetin komplikasyonlarında magnezyumun rolünün netleşmesi için randomize kontrollü çalışmalara ihtiyaç vardır.

Anahtar Kelimeler: Diyabetes Mellitus, magnezyum, proteinüri

\section{Giriş}

Diyabetes Mellitus (DM); küresel ölçekte yaygın görülen, kronik, metabolik hastalıkların başında gelmektedir. Patogenezinde insülin salınımında bozulma, periferik dokularda insülin direnci gelişimi ve genetik değişiklik gibi birçok mekanizmanın rol aldığı bu hastalık, neden olduğu mikro ve makrovasküler komplikasyonlarla beraber önemli bir halk sağlığı sorunudur. DM patogenezinde; çinko (Zn), magnezyum $(\mathrm{Mg})$ ve bakır $(\mathrm{Cu})$ gibi elementler ile vitamin D'nin önemli rol oynadığ 1 bildirilmiştir (1). Nitekim bu parametrelerin değişimi insülin ve glukoz metabolizmasında bozulmalara neden olmaktadır $(2,3)$.

$\mathrm{Mg}$, potasyumdan sonra hücre içinde ikinci sıklikta bulunan katyondur. Enzimatik reaksiyonlarda kofaktör olarak görev alan Mg'nin plazma düzeyindeki azalma birçok klinik tablo ile ilişkilendirilmiş tir. Bunlardan bazıları anksiyete, migren, kardiyak ileti bozuklukları, endotel disfonksiyonu, insülin direnci gelişimi ve glukoz metabolizma bozukluğudur (4).

Literatürde DM patogenezinde, düşük Mg düzeyinin insülin salınımında bozulma, insülin direnci gelişimi ve kötü glisemik kontrol ile ilişkili olabileceğini öne süren yayınlar mevcuttur (5). Diğer yandan son yıllarda yapılan bazı çalışmalarda hücre dışı Mg düzeyinin insülin sekresyonu üzerine belirgin bir etkisinin olmadığı gösterilmiştir (6). Bu çalışmada, DM hastalarında Mg düzeyi ile glukoz regülasyonu, proteinüri ve metabolik parametreler arasındaki ilişkilerin incelenmesi amaçlandı.

\section{Gereç ve Yöntem}

Kesitsel nitelikte bir klinik araştırma olan bu çalışma için gerekli etik kurul onayı Balıkesir Üniversitesi Tıp Fakültesi Etik Kurulu'ndan 19.10.2016 tarih ve 2016/102 sayılı kararıyla alındı. Çalışma kapsamında Ocak 2014 ile Aralık 2015 tarihleri arasında Balıkesir Üniversitesi Tıp Fakültesi İç Hastalıkları Anabilim Dalı polikliniğine başvuran hastalara ait veriler otomasyon sistemi üzerinden retrospektif olarak tarandı. Çalışmaya 18 ile 80 yaş aralığındaki tip-2 DM hastaları dahil edildi. Tiroid fonksiyon bozukluğu, kronik böbrek ve karaciğer hastalığı olan hastalar çalışmaya dahil edilmemiştir. Çalışma kapsamında toplam 200 tip-2 DM hastası değerlendirildi. Olgular Mg düzeyine göre hipomagnezemik ve normomagnezemik olmak üzere iki gruba ayrıldı. Bu iki grup glisemik kontrol, metabolik parametreler ve proteinüri düzeyleri açısından karşılaştırıldı.

Biyokimyasal parametreler Beckman Coulter AU680 (Kalifornia, ABD) marka cihazla ve spektrofotometrik yöntem kullanılarak ölçüldü. HbAlc düzeyleri Adams marka HA-8160 (Osaka, Japonya) kodlu cihaz kullanılarak ve yüksek performanslı sıvı kromatografi yöntemi ile ölçüldü. Proteinüri düzeyinin ölçümü için spot idrarda protein ve kreatinin düzeylerinin oranı kullanıldı. $\mathrm{Mg}$ düzeyinin alt sınırı erkeklerde 1,8 mg/dl, kadınlarda 1,9 mg/dl olarak kabul edildi.

İstatistiksel analiz SPSS versiyon 15.0 yazılımı kullanılarak yapıldı. Değişkenlerin normal dağılıma uygunluğu görsel (histogram ve olasılık grafikleri) ve analitik yöntemlerle (Kolmogorov-Smirnov / Shapiro-Wilk testleri) incelendi. Tanımlayıcı analizler, normal dağılan değişkenler için ortalama ve standart sapmalar kullanılarak verildi, Pearson Ki-kare ve Fisher's Exact testleri ile karşılaştırıldı. 
Verilerin normal dağılım göstermediği durumlarda ikili gruplar Mann-Whitney U testi ile değerlendirildi. Normal dağılım gösteren bağımsız gruplarda student-T testi ve varyans analizinde Levene testi kullanıldı. Tip 1 hata düzeyinin \% 5'in altında olduğu durumlar istatistiksel olarak anlamlı kabul edildi. Mg düzeyi ile glisemik kontrol ve metabolik parametreler, proteinüri miktarı arasındaki ilişkinin incelenmesinde Spearman korelasyon testi kullanıldı.

\section{Bulgular}

Bu çalışmada değerlendirilen olguların $(n=200)$ 59'u $(\% 29,5)$ erkek ve 141'i $(\% 70,5)$ kadın hastaydı. Olguların cinsiyete göre $\mathrm{Mg}$ düzeylerinin karşılaştırılması Tablo 1'de verilmiştir. Tüm grupta hipomagnezemi sıklığ $\% 38,5$ düzeyinde saptand. Hastaların cinsiyetlerine göre $\mathrm{Mg}$ düzeyi incelendiğinde kadınlarda hipomagnezemi görülme oranı $(\% 46,1)$ erkeklere $(\% 20,3)$ göre anlamlı olarak yüksek bulundu $(p=0,001)$.

Tablo 1. Olguların cinsiyete göre Mg düzeylerinin karşılaştırılması

\begin{tabular}{|c|c|c|c|c|c|c|c|}
\hline & \multicolumn{6}{|c|}{ Cinsiyet } & \multirow{3}{*}{$p$} \\
\hline & \multicolumn{2}{|c|}{ Erkek } & \multicolumn{2}{|c|}{ Kadın } & \multicolumn{2}{|c|}{ Toplam } & \\
\hline & $\mathbf{n}$ & $\%$ & $\mathbf{n}$ & $\%$ & $\mathbf{n}$ & $\%$ & \\
\hline Normomagnezemi & 47 & $(79,7)$ & 76 & $(53,9)$ & 123 & $(61,5)$ & \multirow{3}{*}{$0,001 *$} \\
\hline Hipomagnezemi & 12 & $(20,3)$ & 65 & $(46,1)$ & 77 & $(38,5)$ & \\
\hline Toplam & 59 & $(100,0)$ & 141 & $(100,0)$ & 200 & $(100,0)$ & \\
\hline
\end{tabular}

Hastalar hipomagnezemik ve nornomagnezemik olmak üzere iki alt gruba ayrılıp glisemik kontrol ve diğer metabolik parametreler açısından karşılaştırıldı (Tablo 2). Hipomagnezemi grubunda glukoz düzeyinin $(179,7 \pm 60,2 \mathrm{mg} / \mathrm{dl})$, normomagnezemi grubuna göre $(160,7 \pm 52,3 \mathrm{mg} / \mathrm{dl})$ daha yüksek olduğu saptandı $(p=0,013)$. Bununla birlikte gruplar arasında HbAlc düzeyi yönünden istatistiksel anlamda bir farklılık gözlenmedi. Proteinüri düzeyi hipomagnezemi grubunda $(0,18 \pm 0,12 \mathrm{mg} / \mathrm{mg})$, normomagnezemi grubuna göre $(0,14 \pm 0,09 \mathrm{mg} / \mathrm{mg})$ daha yüksek saptandı $(p=0,013)$.

Tablo 2. Olguların Mg düzeyine göre glukoz, proteinüri ve metabolik parametrelerinin karşılaştırılması

\begin{tabular}{|c|c|c|c|c|c|}
\hline & \multicolumn{2}{|c|}{$\begin{array}{c}\text { NORMOMAGNEZEMI } \\
(\mathrm{n}=\mathbf{1 2 3})\end{array}$} & \multicolumn{2}{|c|}{$\begin{array}{c}\text { HIPOMAGNEZEMİ } \\
(\mathrm{n}=77)\end{array}$} & \multirow[t]{2}{*}{$p$} \\
\hline & Ortalama & $\pm \mathbf{s s}$ & Ortalama & \pm ss & \\
\hline HGB ( g/dl ) & 13,5 & 1,3 & 13,0 & 1,1 & $0,014 \dagger$ \\
\hline GLUKOZ (mg/dl ) & 160,7 & 52,3 & 179,7 & 60,2 & $0,013 *$ \\
\hline HbA1c & 7,9 & 1,5 & 8,3 & 1,7 & $0,190 *$ \\
\hline ÜRE (mg/dl ) & 30,0 & 6,7 & 29,6 & 6,9 & $0,737 *$ \\
\hline KREATININ (mg/dl ) & 0,9 & 0,1 & 0,8 & 0,1 & $0,097 *$ \\
\hline ALT (U/L) & 18,7 & 6,2 & 18,9 & 6,1 & $0,887 *$ \\
\hline $\operatorname{AST}(\mathbf{U} / \mathbf{L})$ & 18,2 & 4,3 & 18,3 & 4,7 & $0,843 *$ \\
\hline KOLESTEROL (mg/dl) & 202,4 & 40,6 & 202,6 & 34,4 & $0,971 \dagger$ \\
\hline LDL-K (mg/dl) & 122,9 & 33,6 & 118,1 & 31,0 & $0,314 \dagger$ \\
\hline HDL-K (mg/dl) & 47,4 & 11,6 & 49,5 & 11,7 & $0,225 \dagger$ \\
\hline TGL (mg/dl) & 165,2 & 86,3 & 175,0 & 91,3 & $0,476^{*}$ \\
\hline $\begin{array}{l}\text { SPOT İDRAR KREATİNİN } \\
(\mathrm{mg} / \mathrm{dl})\end{array}$ & 123,7 & 64,3 & 100,6 & 50,8 & $0,023^{*}$ \\
\hline $\begin{array}{l}\text { SPOT İDRAR PROTEİN } \\
(\mathrm{mg} / \mathrm{dl})\end{array}$ & 16,1 & 9,8 & 17,9 & 12,8 & $0,832 *$ \\
\hline $\begin{array}{l}\text { PROTEİNÜRİ MİKTARI } \\
\text { (mg/mg) }\end{array}$ & 0,14 & 0,09 & 0,18 & 0,12 & $0,013 *$ \\
\hline
\end{tabular}

Kısaltmalar: Hgb: Hemoglobin, HbA1c: Glikolize Hemoglobin A1c, ALT: Alanin aminotransferaz, AST: Aspartat aminotransferaz, HDL-K: Yüksek dansiteli lipoprotein kolesterol, LDL: Düşük dansiteli lipoprotein kolesterol, TGL: Trigliserid, ss: standart sapma 
Mg düzeyi ile diğer parametreler arasındaki ilişki incelendiğinde; $\mathrm{Mg}$ ile glukoz düzeyi arasında negatif yönde zayıf bir korelasyon ( $\mathrm{r}=-0,201$ ve $p=0,004)$, HbAlc düzeyi arasında negatif yönde zayıf bir korelasyon ( $\mathrm{r}=-0,166$ ve $p=0,018)$ ve proteinüri düzeyi arasında negatif yönde zayıf bir korelasyon ( $\mathrm{r}=$ $-0,167$ ve $p=0,0018$ ) saptandı (Şekil 1, 2 ve 3). Diğer parametrelerle Mg düzeyi arasında anlamlı bir ilişki gözlenmedi.

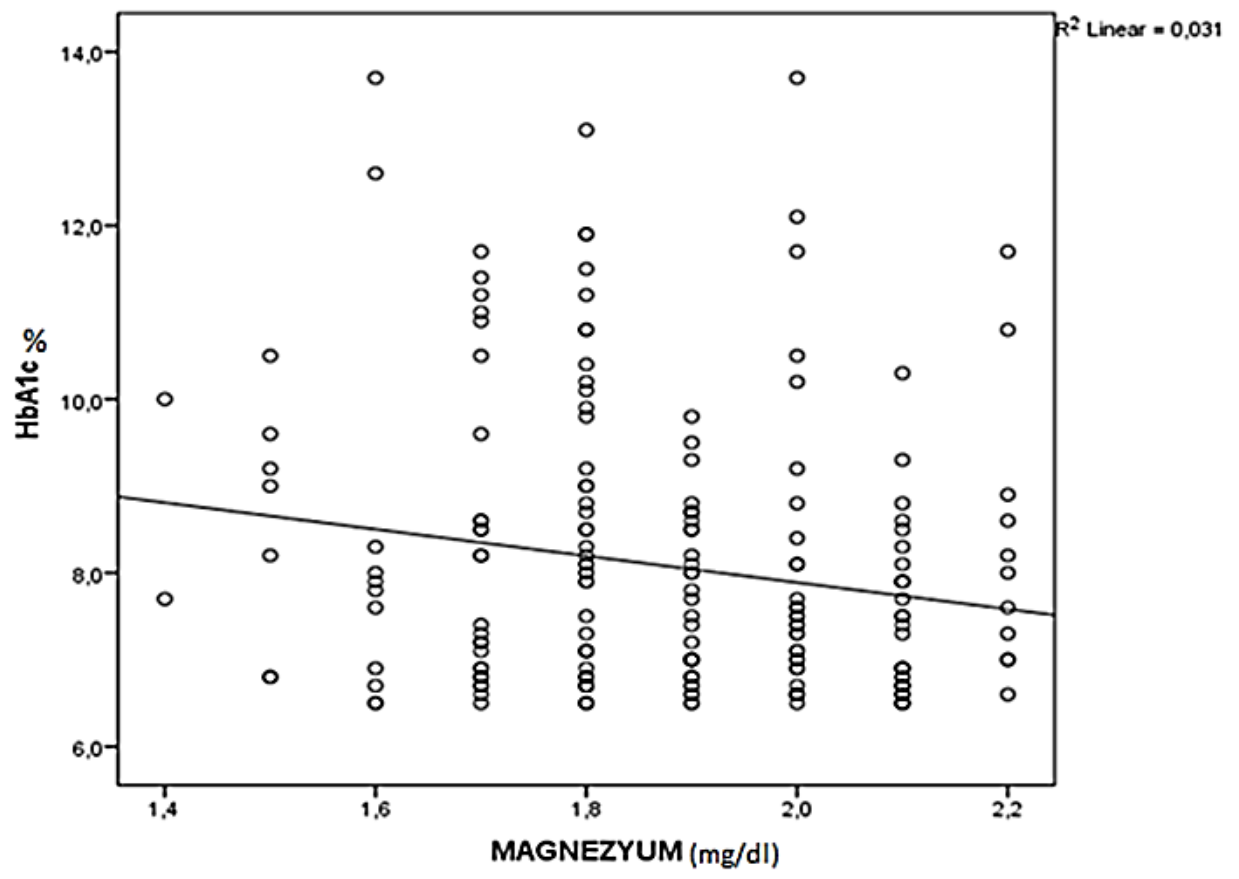

Şekil 1. Mg ile HbAlc düzeyi arasındaki korelasyon grafiği

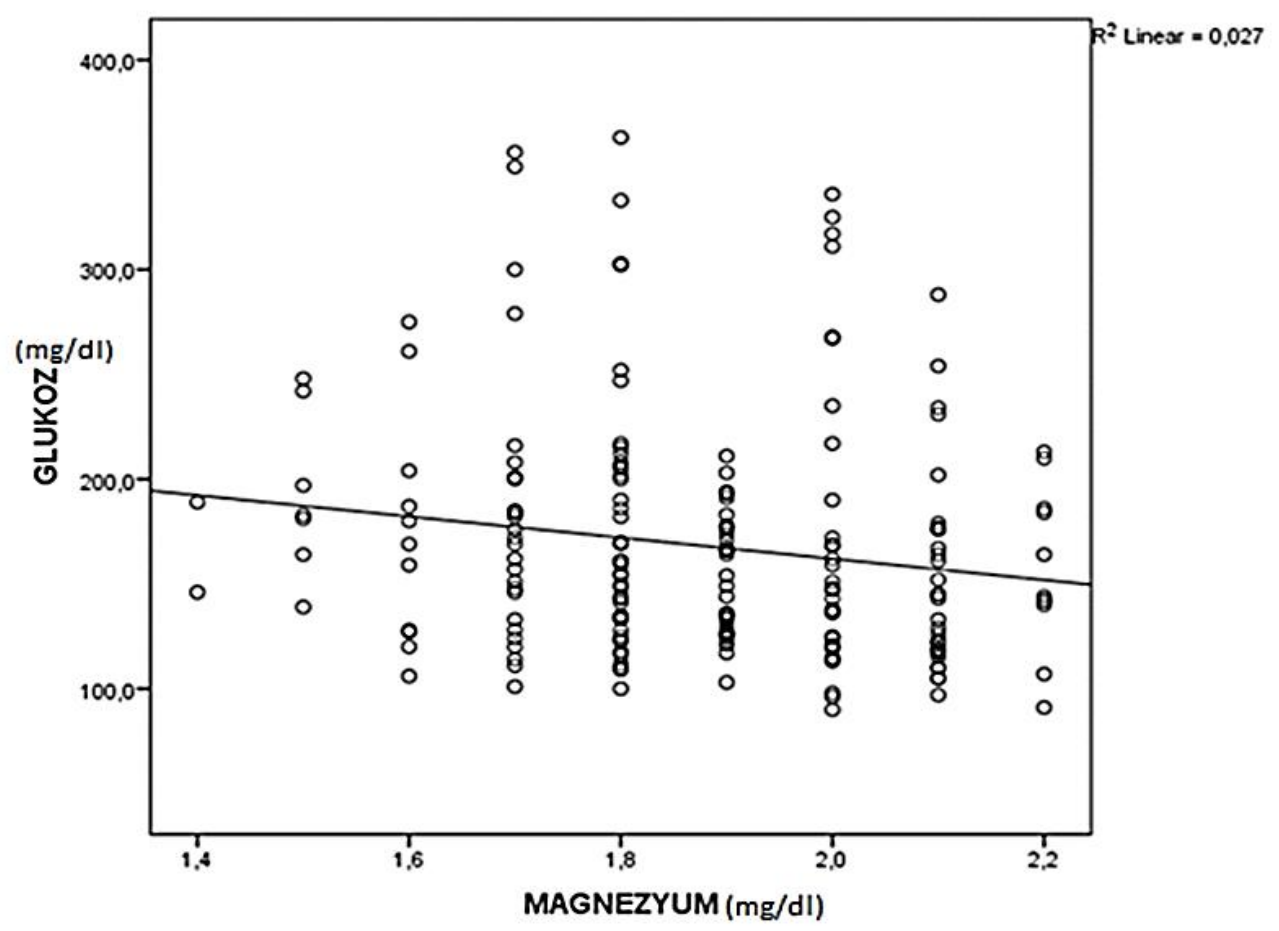

Şekil 2. Mg ile glukoz düzeyi arasındaki korelasyon grafiği 


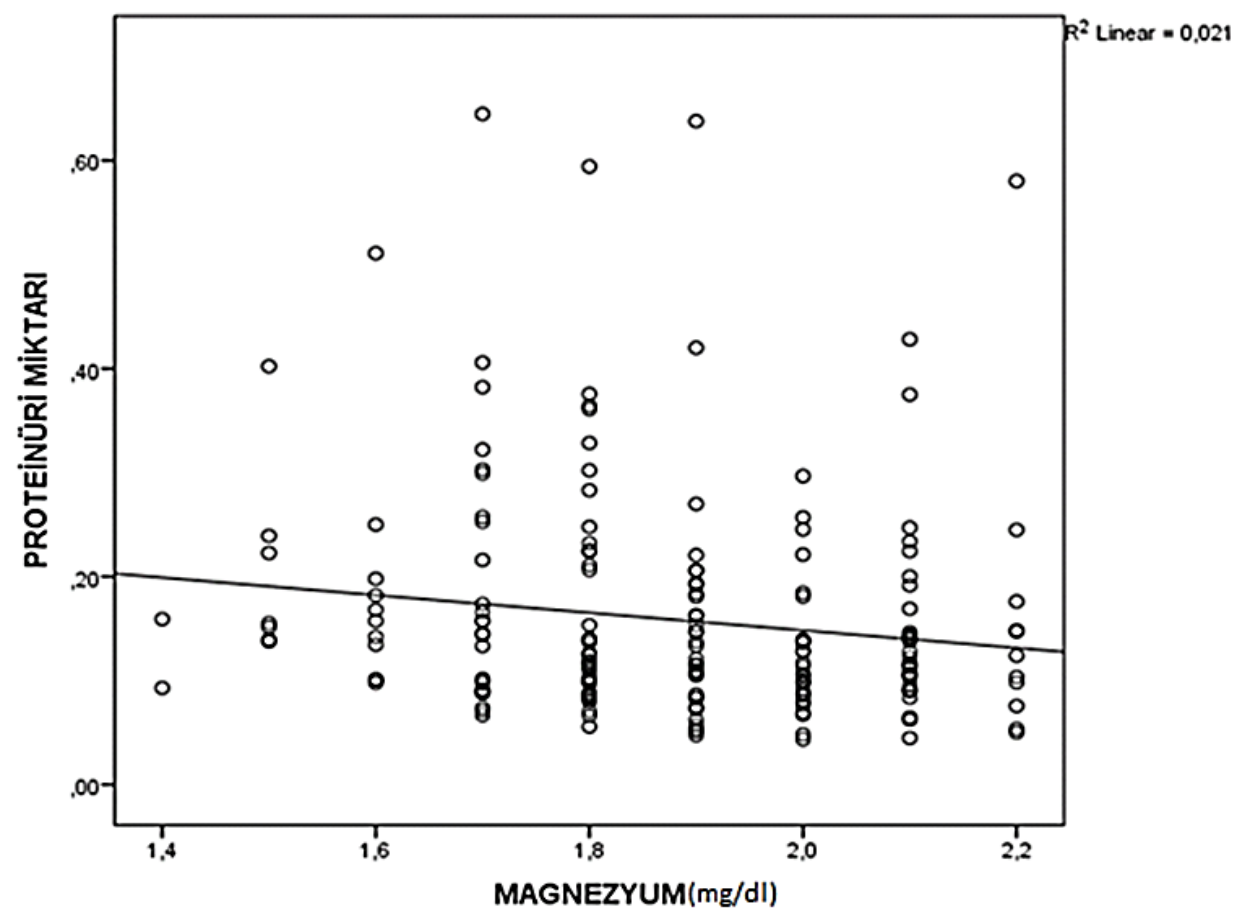

Şekil 3. Mg ile proteinüri miktarı arasındaki korelasyon grafiği

\section{Tartışma}

Bu çalışmada Mg’nin DM hastalarında glisemik ve metabolik parametreler üzerindeki etkisi incelendi. Çalışma kapsamında DM hastalarındaki hipomagnezemi sıklığı belirgin ölçüde yüksek izlendi. Ayrıca diyabetik hastaların hipomagnezemi görülme oranı kadınlarda erkeklere oranla yüksek gözlendi. $\mathrm{Mg}$ düzeyi düşük olan hastalarda açlık kan şekeri düzeyinin daha yüksek olduğu tespit edildi. Bununla beraber Mg ile HbA1c arasında anlamlı bir ilişki gözlenmedi. Diyabetik nefropati açısından düşük $\mathrm{Mg}$ seviyesi izlenen hastalarda proteinüri miktarının fazla olduğu gözlendi. Diğer yandan $\mathrm{Mg}$ düzeyi ile glukoz, HbA1c ve proteinüri miktarı arasında negatif yönde zayıf bir korelasyon olduğu tespit edildi. $\mathrm{DM}$ hastalarında kronik dönemde birçok element $(\mathrm{Zn}, \mathrm{Mg}, \mathrm{Cu}$ ) ve hormon düzeyinde (insülin, $\mathrm{D}$ vitamini) değişiklik gözlenir $(1,7)$. Hastalarda değişik düzeylerde ölçülebilen bu parametrelerden $\mathrm{Mg}$ sıklıkla düşük düzeylerde izlenir (8). Bu durumun başlıca nedenleri arasında ilaç kullanımı (diüretikler, multivitaminler), diyetle yetersiz alım, renal parankim hasarına ikincil kayıplar sıralanabilir (9). $\mathrm{Mg}$ düzeyindeki düşüklük birçok klinik patoloji ile ilişkili olabilir. Bunlardan başlıcaları DM, hipertansiyon (HT), obezite, depresyon, migren ve kardiyovasküler hastalıklardır (4).

$\mathrm{Mg}$ hücre içinde en çok bulunan ikinci katyondur. Enzimatik reaksiyonlarda kofaktör görevi gören Mg'nin organizmada nitrik oksit salınımı, kemik mineralizasyonu, kardiyak elektriksel aktivite, insülin sentezi ve periferik insülin direnci gibi birçok olayda rol aldığı bilinmektedir (4). Pankreas beta hücrelerinde hücre içi Mg'nin pürin nükleotidleri ile oluşturduğu kompleks yapı birer membran proteini olan GLUT 2 ve K-ATP kanalları aracılığıyla insülin sekresyonunda rol almaktadır. Bununla beraber bu kompleks yapı periferal hücre yüzeyinde bulunan insülin reseptörlerinin metabolik etkinliği ile doğrudan ilişkilidir (2). Düşük magnezyum düzeylerinde hücre içi tirozin kinaz enzim aktivitesindeki bozulmaya sekonder periferik insülin direnci gelişimi tetiklenebilir (10). Bu patogenetik mekanizmalara bağlı olarak DM hastalarında azalmış Mg düzeyleri pankreas beta hücre disfonksiyonuna, periferik insülin direnci gelişimine ve glukoz metabolizma bozukluğuna neden olmaktadır. Bu çalışmada hipomagnezemi izlenen grupta açlık plazma glukoz düzeyi yüksek izlenmiş olup mevcut literatürle uyumlu bulundu. $\mathrm{Mg}$ ile $\mathrm{HbA} 1 \mathrm{c}$ arasında istatistiksel olarak anlamlı bir ilişki bulunmaması, çalışmanın kesitsel bir çalışma olması ve HbA1c'nin uzun dönem seyrinin incelenememesine bağlı olabileceği düşünüldü. 
DM hastalarında gelişen mikrovasküler koplikasyonlar ile Mg düzeyi arasında ilişki mevcuttur (11). $\mathrm{Mg}$ vasküler endoteliyal sistemde nitrik oksit salınımı üzerinden vazodilatatör etki göstermektedir. Ayrıca pro-inflamatuar sitokin salınımı üzerine negatif inhbitör etki gösterir. Bununla beraber Mg'nin serbest radikal oluşumunu azaltıp anti-oksidatif etkisi vardır (12). Düşük $\mathrm{Mg}$ düzeyinin artmış vasküler kalsifikasyonla ilişkili olabileceği yapılan çalışmalarda belirtilmiştir (13). Literatürde HT, DM gibi kronik hastalıkların patogenezinde de bu mekanizmalara ikincil olarak vasküler komplikasyonlarda artış olduğunu gösteren çalışmalar mevcuttur $(14,15)$. Gerek artmış oksidatif stres gerekse proinflamatuar sitokinler aracılığıyla DM hastalarında $\mathrm{Mg}$ düşüklüğüne ikincil renal parankimal hasar gelişimi gözlenebilir. Bu durum diyabetik nefropati izlenen hastalarda ortaya çıkan proteinürinin artmasına neden olur. Bu çalışmada hipomagnezemi izlenen diyabetik hastalarda proteinüri miktarı normomagnezemik olan gruba kıyasla daha yüksek düzeyde izlendi.

Bu çalışmada birtakım kısıtlılıklar mevcuttur. Diyabetik hastalarla yapılan bu çalışma kesitsel bir çalışma olup Mg düzeyi değişiminin klinik etkinliği incelenemedi. Hastaların geriye dönük taramasında vücut kitle indeksi, kan basıncı ve insülin direnci indeksi (HOMA-IR) takibine ulaşılamadığından bu parametrelerin Mg ile korelasyonu yapılamadı. Son olarak çalışma tek merkezli planlanmış olup toplum genelini yansıtma açısından kısıtlı veriye sahiptir.

\section{Sonuç}

DM hastalarında Mg düzeyi diyet, ilaç kullanımı vb. birçok duruma bağlı olarak düşük izlenebilmektedir. $\mathrm{Mg}$ düzeyindeki azalma glisemik regülasyonda bozulma, proteinüri miktarında artışa neden olabilir. Mg'nin DM hastalarında gelişen komplikasyonlardaki rolünün netleşmesi için randomize kontrollü çalışmalara ihtiyaç vardır.

\section{Çıkar Çatışması}

Yazarlar, herhangi bir çıkar çatışması bildirmemişlerdir.

\section{Kaynaklar}

1. Cheng WW, Zhu Q, Zhang HY. Mineral Nutrition and the Risk of Chronic Diseases: A Mendelian Randomization Study. Nutrients. 2019;11(2). pii: E378.

2. Kostov K. Effects of Magnesium Deficiency on Mechanisms of Insulin Resistance in Type 2 Diabetes: Focusing on the Processes of Insulin Secretion and Signaling. Int J Mol Sci. 2019;20(6). pii: E1351.

3. Harinarayan CV. Vitamin D and diabetes mellitus. Hormones. 2014;13(2):163-81.

4. Gröber U, Schmidt J, Kisters K. Magnesium in Prevention and Therapy. Nutrients. 2015;7(9):8199-226.

5. Joy SS, George TP, Siddiqui K. Low magnesium level as an indicator of poor glycemic control in type 2 diabetic patients with complications. Diabetes\&Metabolic Syndrome: Clinical Research \& Reviews 2019;13(2):1303-07.

6. Gommers LMM, Hill TG, Ashcroft FM, De Baaij JHF. Low extracellular magnesium does not impair glucose-stimulated insulin secretion. PLoS One. 2019; 14(6): e0217925.

7. Issa CM. Vitamin D and Type 2 Diabetes Mellitus. Adv Exp Med Biol. 2017;996:193-205.

8. Kurstjens S, De Baaij JH, Bouras H, Bindels RJ, Tack CJ, Hoenderop JG. Determinants of hypomagnesemia in patients with type 2 diabetes mellitus. Eur J Endocrinol. 2017; 176(1): 1119.

9. Kaur B, Henry J. Micronutrient status in type 2 diabetes: a review. Adv Food Nutr Res. 2014;71:55-100. 
10. Barbagallo M, Dominguez LJ. Magnesium metabolism in type 2 diabetes mellitus, metabolic syndrome and insulin resistance. Arch Biochem Biophys. 2007; 458(1): 40-7.

11. Sales CH, Pedrosa LF. Magnesium and diabetes mellitus: their relation. Clin Nutr. 2006; 25(4): 554-62.

12. Kolte D, Vijayaraghavan K, Khera S, Sica DA, Frishman WH. Role of magnesium in cardiovascular diseases. Cardiol Rev. 2014; 22(4): 182-92.

13. Massy ZA, Drüeke TB. Magnesium and outcomes in patients with chronic kidney disease: focus on vascular calcification, atherosclerosis and survival. Clin Kidney J. 2012; 5(1): i52-i61.

14. D Arpaci, A G Tocoglu, H Ergenc, S Korkmaz, A Ucar, A Tamer. Associations of serum Magnesium levels with diabetes mellitus and diabetic complications. Hippokratia. 2015; 19(2): 153-57.

15. Lu J, Gu Y, Guo M, Chen P, Wang H, Yu X. Serum Magnesium Concentration Is Inversely Associated with Albuminuria and Retinopathy among Patients with Diabetes. J Diabetes Res. 2016;2016:1260141. 